\title{
Five microRNAs in serum as potential biomarkers for prostate cancer risk assessment and therapeutic intervention
}

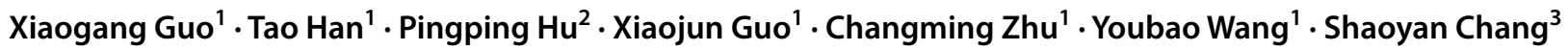

Received: 3 August 2018 / Accepted: 8 October 2018 / Published online: 15 October 2018

(c) The Author(s) 2018

\begin{abstract}
Background Prostate cancer (PCa) is a common malignant human tumor and one of the main causes of cancer-related deaths in men. At present, prostate-specific antigen levels are widely used to diagnose $\mathrm{PCa}$ in the clinic, but they are not sufficient for an accurate early diagnosis or prognosis.

Methods To identify potential molecular markers for PCa, we used real-time PCR to measure the expression levels of various microRNAs, including miR-1825, miR-484, miR-205, miR-141, and let-7b, in the serum of 72 PCa patients and 34 healthy controls.

Results miR-1825, miR-484, miR-205, miR-141, and let-7b were shown to be highly specific for PCa, suggesting that they could be used as PCa tumor screening biomarkers. miR-205 may also be used as a biomarker for indicating bone metastasis in PCa patients, miR-1825 levels may help indicate tumor-node-metastasis classification, the evaluation of treatment effects, and determining prognosis, while let-7b levels may indicate potential tumor malignancy and the hormone resistance status and could be used as a basis to adjust individual treatments for the high-risk, early diagnosis of refractory PCa.

Conclusion This study identified possible PCa tumor markers to more accurately predict the occurrence, progression, and prognosis of $\mathrm{PCa}$, and which could be used in the development of tumor drug therapy.
\end{abstract}

Keywords Prostate cancer $\cdot$ MiR-1825 $\cdot$ MiR-484 $\cdot$ MiR-205 $\cdot$ MiR-141 $\cdot$ Let-7b

\section{Introduction}

Prostate cancer $(\mathrm{PCa})$ is the most common malignant tumor in humans and one of the main causes of male cancer-related deaths [1]. Several tumor markers for PCa have already been identified, including prostate-specific antigen (PSA); however, these can be affected by confounding factors such as

Xiaogang Guo and Tao Han have contributed equally to this work.

Electronic supplementary material The online version of this article (https://doi.org/10.1007/s11255-018-2009-4) contains supplementary material, which is available to authorized users.

Shaoyan Chang

changsyan_2001@163.com

1 Urology Department of Urology, Haici Medical Group of Qingdao, Qingdao, Shandong, China

2 Department of Cardiology, Jimo People's Hospital, Qingdao, Shandong, China

3 Beijing Municipal Key Laboratory of Child Development and Nutriomics, Capital Institute of Pediatrics, Beijing, China benign prostatic hyperplasia $(\mathrm{BPH})$, prostate gland inflammation, and prostate massage [2].

Micro (mi) RNAs are non-coding, single-stranded RNA molecules approximately 22 nucleotides in length that are involved in regulating many biological processes [3]. They both suppress and activate the expression of genes by directly binding to target mRNAs for the degradation or inhibition of protein translation. Novel tumor markers are required for $\mathrm{PCa}$ to determine its development and progression, and miRNAs are a promising target for tumor drug therapy [4].

Whole genome expression profiling was previously used to identify possible roles for miRNAs 1234, 1238, 1913, 489-5p, 1825, 484, and 483-5p in the development, progression, or suppression of PCa [5]. Additionally, miR-205 is mainly expressed on the basal cells of prostate tissue, and inhibits the targets of zinc finger E-box-binding proteins, PKC $\varepsilon$ and HMGB3 to inhibit tumor proliferation and apoptosis and cancer cell aggressiveness [6, 7]. The let-7 family may also play an important role in the recurrence and metastasis of PCa by regulating tumor stem cells [8]. Let-7b 
was shown to inhibit the expression of enhancer of zeste homolog (EZH)2 and the growth of PCa cells, and low let$7 \mathrm{~b}$ expression may be associated with PCa recurrence and tumor hormone resistance [9].

miR-141 is located on chromosome 12 and its pre-miRNA precursor produces two mature miRNAs, miR-141-3p and miR-141-5p, in the cytoplasm [10]. miRDB database analysis showed that the androgen receptor (AR) was a possible target gene of miR-141-3p, which was effective in targeted AR treatment of $\mathrm{PCa}[11,12]$. These studies provide a theoretical basis for the application of miRNAs in $\mathrm{PCa}$, and suggest that they could be used as molecular diagnostic markers. However, many studies are limited to cellular investigations or the analysis of limited clinical samples.

In this study, we used real-time PCR to detect the expression of miRNAs, including miR-1825, miR-484, miR-205, miR-141, and let-7b, in 72 patients with PCa and 34 healthy controls. Several stratified analyses were carried out to study the expression of these miRNAs, with the aim of identifying potential molecular markers for the diagnosis and drug therapy assessment of PCa.

\section{Materials and methods}

\section{Sample collection}

We collected serum samples from 72 patients diagnosed with PCa by biopsy or surgical specimen pathology in our hospital from July 2015 to September 2016. Thirty-four healthy individuals were enrolled in the control group. They do not have prostatic hyperplasia confirmed by magnetic resonance and ultrasound and prostatitis examined from their prostatic fluid. Patients with a history or current diagnosis of tumors, diabetes, hypertension, urinary tract diseases such, or related immune or infectious diseases were excluded. Blood samples were collected from all participants in a vacuum tube of anticoagulation, then centrifuged at $3000 \times g$ for $10 \mathrm{~min}$. The separated plasma was aliquoted and stored at $-80{ }^{\circ} \mathrm{C}$. The study was approved by the ethics committee of the local institution and performed in accordance with the principles of the Declaration of Helsinki. Subject information is shown in Table 1.

\section{miRNA extraction and reverse transcription}

miRNA was extracted from serum samples using the Serum MicroRNA Extraction and Purification Kit (Shanghai Novland, Shanghai, China) and stored at $-80^{\circ} \mathrm{C}$. Reverse transcription was carried out at $16{ }^{\circ} \mathrm{C}$ for $30 \mathrm{~min}, 42{ }^{\circ} \mathrm{C}$ for $30 \mathrm{~min}$, then $85^{\circ} \mathrm{C}$ for $10 \mathrm{~min}$. The reverse transcription system is shown in Table $\mathrm{S} 1$.
Table 1 Characteristic of PCa and control

\begin{tabular}{lll}
\hline Characteristic & PCa & Control \\
\hline $\mathrm{N}$ & 72 & 34 \\
Age & 76.46 & 74.62 \\
PSA treatments & & \\
$<4 \mathrm{ng} / \mathrm{ml}$ & 22 & \\
$>4 \mathrm{ng} / \mathrm{ml}$ & 50 & \\
Gleason score & & \\
$6-7$ & 29 & \\
$8-10$ & 43 & \\
TNM status & & \\
T1-T2 & 39 & \\
T3-T4 & 33 & \\
Bone metastases & & \\
Yes & 34 & \\
No & 38 & \\
Hormone dependency & & \\
Dependence & 23 & \\
Resistance & 25 & \\
\hline
\end{tabular}

Real-time quantitative PCR was performed using primers shown in Table $\mathrm{S} 2$ at $95^{\circ} \mathrm{C}$ for $3 \mathrm{~min}$, then 40 cycles of $95{ }^{\circ} \mathrm{C}$ for $12 \mathrm{~s}$, and $60{ }^{\circ} \mathrm{C}$ for $40 \mathrm{~s}$. Real-time fluorescence quantitative response system is shown in Table S3. Fold changes were calculated using the $2^{-\Delta \Delta \mathrm{CT}}$ method [13].

\section{Statistical analysis}

The experimental results were processed by SPSS version 17.0 software (McGraw-Hill Inc, New York, NY). Data are shown as means \pm standard deviation, and were accurate to 0.01 . Two independent groups were compared with $t$ or rank sum tests. $p<0.05$ was used to indicate statistical significance.

\section{Results}

\section{miRNA levels in PCa patients and healthy control}

We evaluated the levels of miR-1825, miR-484, miR-205, miR-141, and let-7b in the 72 PCa patients and 34 healthy controls, and found significant differences between the two groups (Table S4). In the PCa group, miR-484, miR-205, and let- $7 \mathrm{~b}$ levels were significantly lower than in the control group (Fig. 1b, c, e), while miR-1825 and miR-141 were significantly higher in the control group than the PCa group (Fig. 1a, d). 

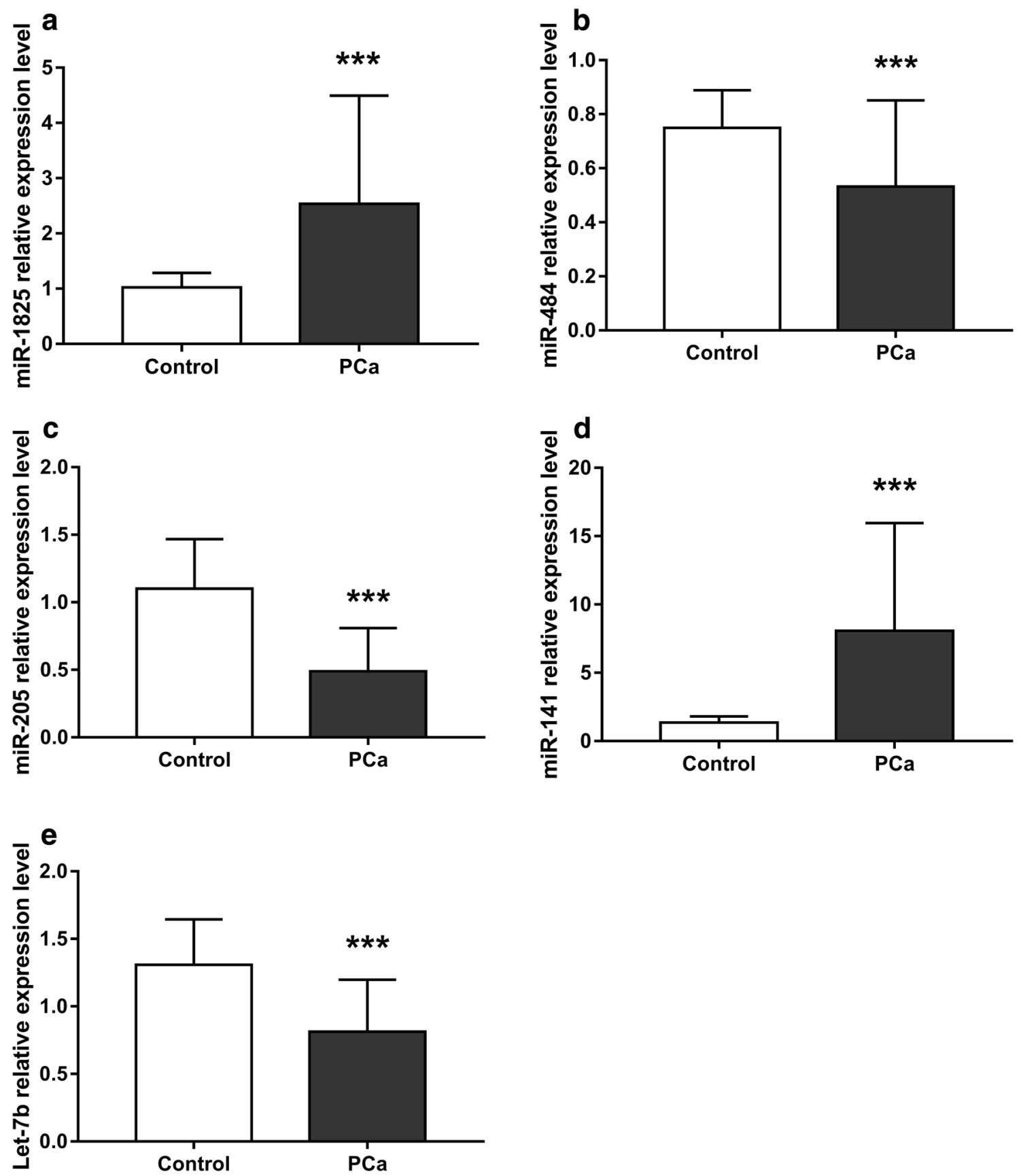

Fig. 1 Relative miRNA expression levels between prostate cancer and control groups. a miR-1825 expression was significantly higher in PCa patients than controls. b miR-484 expression was significantly lower in PCa patients than controls. c miR-205 expression was significantly lower in PCa patients than in controls. d miR-141 expres-

\section{miRNA levels in healthy controls and PCa patients with $\mathrm{PSA}<4 \mathrm{ng} / \mathrm{ml}$ after PCa treatment}

We next examined miRNA levels in the healthy control group and $22 \mathrm{PCa}$ patients whose PSA levels decreased to $<4 \mathrm{ng} / \mathrm{ml}$ after PCa treatment which included endocrine sion was significantly higher in PCa patients than controls. e Let-7b expression was significantly lower in PCa patients than controls. PCa, prostate cancer group; control, healthy group. Results are shown as means \pm SD. $* p<0.05, * * p<0.01, * * * p<0.001$

treatment, surgery, radiotherapy, or combined therapy for more than 1 month. We found a significant difference in the expression of all miRNAs examined between $\mathrm{PCa}$ patients who had undergone treatment and healthy controls (Fig. 2 and Table S5). 

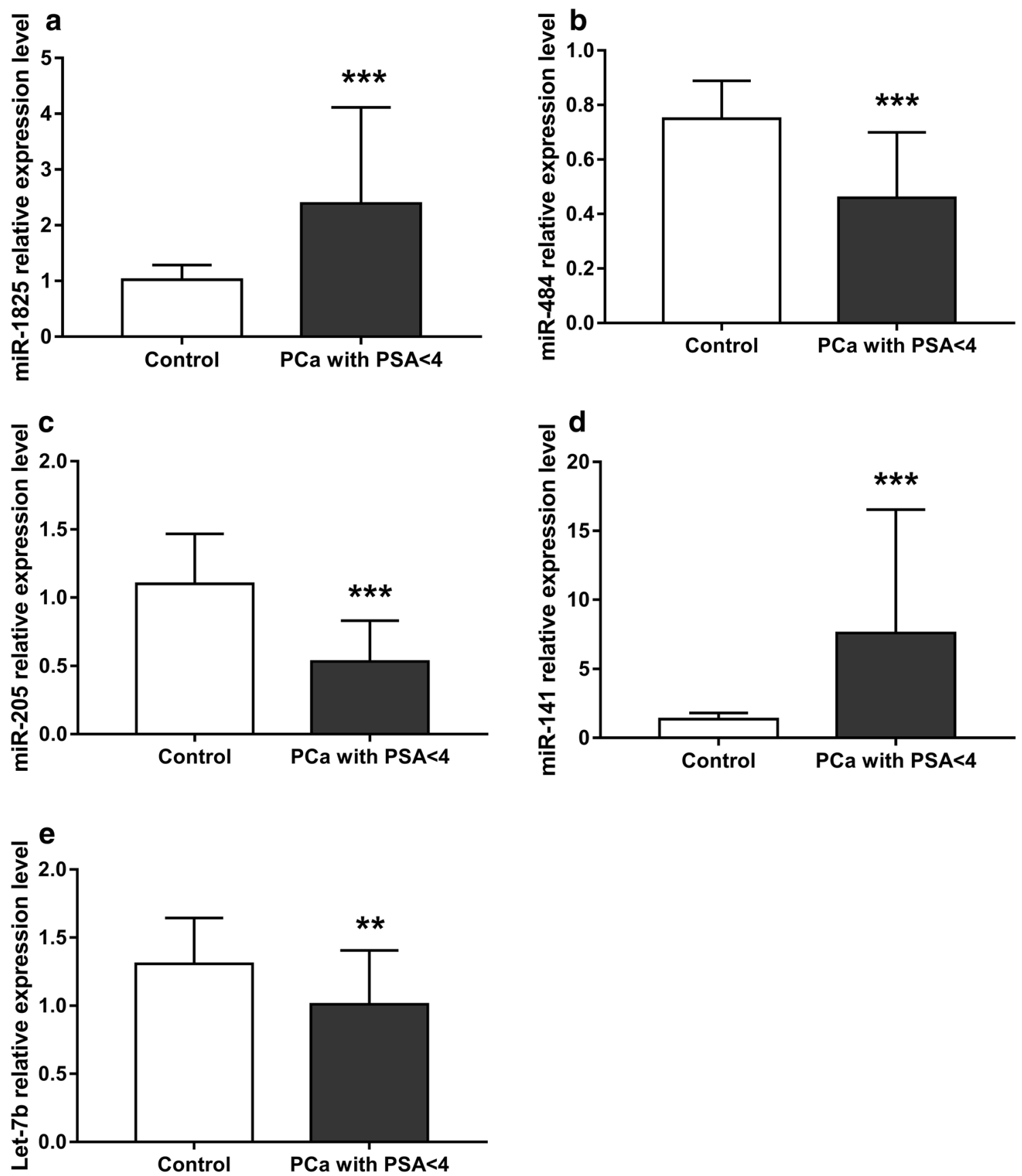

Fig. 2 Relative miRNA expression levels between PCa patients with PSA $(<4 \mathrm{ng} / \mathrm{ml})$ after treatment and control groups. a miR-1825 expression was significantly higher in PCa patients with PSA $<4 \mathrm{ng} /$ $\mathrm{ml}$ than controls. b miR-484 expression was significantly lower in PCa patients with PSA $<4 \mathrm{ng} / \mathrm{ml}$ than controls. $\mathbf{c}$ miR-205 expression was significantly lower in PCa patients with $\mathrm{PSA}<4 \mathrm{ng} / \mathrm{ml}$ than in

control; d miR-141 was significantly higher in PCa with PSA $<4$ than controls. e Let-7b expression was significantly lower in PCa patients with PSA $<4 \mathrm{ng} / \mathrm{ml}$ than controls. PCa with PSA $<4$, prostate cancer patients with PSA $<4 \mathrm{ng} / \mathrm{ml}$ after treatment; control, healthy group. Results are shown as means \pm SD. $* p<0.05$, ** $p<0.01$, *** $p<0.001$

\section{miRNA levels before and after treatment in the same PCa patients}

In a series of subgroup analyses, we examined changes in miRNA levels before and after treatment within the same

PCa patient group. Only miR-1825 expression was shown to change significantly following treatment, with a significant decrease observed (Fig. 3a, Fig. S1, and Table S6). 

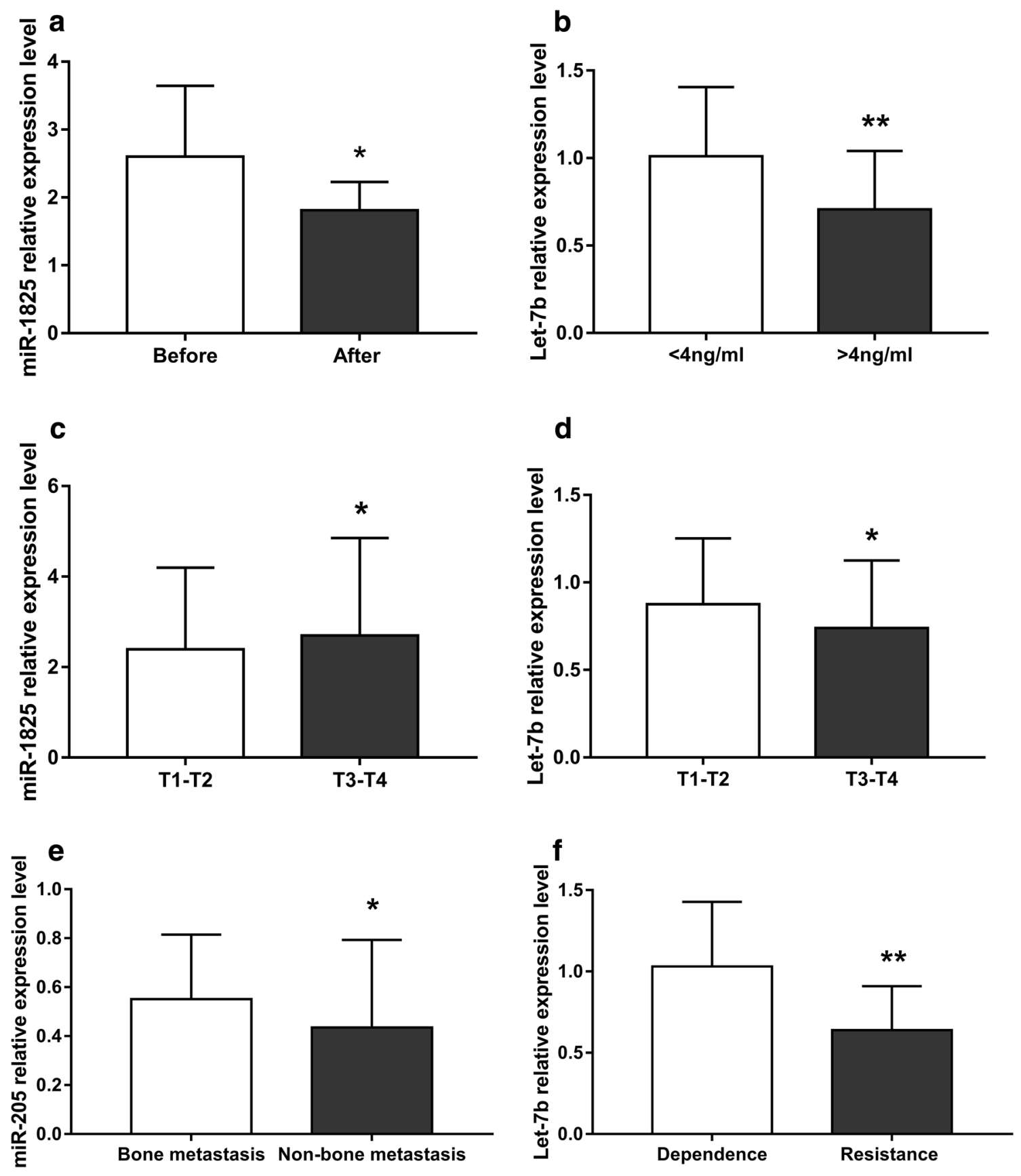

Fig. 3 Relative miRNA expression in multiple stratified analysis. a miR-1825 expression was significantly higher before treatment than after. b Let-7b expression was significantly higher in patients with $\mathrm{PSA}<4 \mathrm{ng} / \mathrm{ml}$ than those with PSA $>4 \mathrm{ng} / \mathrm{ml}$. c miR-1825 expression was significantly higher in patients at stage T3-T4 than those at stage T1-T2. d Let-7b expression was significantly lower in patients at stage T3-T4 than those at stage T1-T2. e miR-205 expression was significantly higher in patients with bone metastasis than in those without. f Let-7b expression was significantly higher in hormone-

miRNA levels in PCa patients according to PSA levels

We next examined miRNA levels in PCa patients stratified dependent group than in hormone-resistant group: before, prostate cancer patients treated without PSA; after, prostate cancer patients treated without PSA. PSA $<4$, PCa patients treated with PSA $<4 \mathrm{ng} /$ $\mathrm{ml}$; PSA $>4$, PCa patients treated with PSA $>4 \mathrm{ng} / \mathrm{ml}$. T1-T2, low TNM score group; T3-T4, high TNM score group. Dependent, PCa patients in the hormone-dependent group; resistant, PCa patients in the hormone-resistant group. Results are shown as means $\pm \mathrm{SD}$. $* p<0.05$

according to PSA levels regardless of any treatment: the $\mathrm{PSA}<4 \mathrm{ng} / \mathrm{ml}$ group and PSA $>4 \mathrm{ng} / \mathrm{ml}$ group. Only the expression of let- $7 \mathrm{~b}$ differed significantly between the two 
groups, being significantly higher in the PSA $<4 \mathrm{ng} / \mathrm{ml}$ group than in the PSA $>4 \mathrm{ng} / \mathrm{ml}$ group (Fig. 3b, Fig. S2, and Table S7).

\section{miRNA levels according to tumor-node-metastasis (TNM) score}

We also examined miRNA levels in PCa patients divided according to TNM stage. We found that miR-1825 expression was significantly increased in T3-T4 stage patients than T1-T2 stage patients (Fig. 3c and Table S8). By contrast, let-7b expression was significantly decreased in T3-T4 stage compared with T1-T2 stage patients (Fig. 3d, Fig. S3, and Table S8).

\section{miRNA levels according to bone metastasis}

Bone metastasis in PCa patients was diagnosed using computed tomography (CT), magnetic resonance imaging, and emission CT. Examining miRNA levels in patients according to the presence or absence of bone metastasis showed that only miR-205 was significantly different between the two groups, being higher in patients with bone metastasis than without (Fig. 3e, Fig. S4, and Table S9).

\section{miRNA levels in hormone-dependent and -resistant patients}

After treatment, hormone-dependent PCa patients showed normal levels of PSA $(<4 \mathrm{ng} / \mathrm{ml})$. However, PSA levels rose again in some PCa patients who received endocrine therapy, indicating that they were hormone-resistant. We observed a significant difference in let- $7 \mathrm{~b}$ expression between hormonedependent and hormone-resistant patients with lower level in hormone-resistant group than hormone-dependent group (Fig. 3f, Fig. S5, and Table S10).

\section{Receiver operating characteristic (ROC) curve analysis of the diagnostic value of miR-1825, miR-484, miR-205, miR-141, and let-7b in PCa}

miR-1825 expression was shown to be able to distinguish PCa patients from healthy controls, with ROC curve analysis revealing a cut-off value of 1.368 , a specificity of $91.2 \%$, a sensitivity of $93.1 \%$, an area under the curve of 0.957 , and a 95\% confidence interval of 0.916-0.997 (Fig. S6a). Similar analyses for other miRNAs revealed values of $0.590,69.4 \%, 88.2 \%, 0.786$, and $0.702-0.871$, respectively, for miR-484 (Fig. S6b), 0.668, 100\%, 77.78\%, 0.914, and 0.860-0.967, respectively, for miR-205 (Fig. S6c), 2.459, $100 \%, 87.5 \%, 0.929$, and $0.873-0.984$, respectively, for
miR-141 (Fig. S6d), and 0.972, 88.2\%, 72.2\%, 0.848, and $0.775-0.921$, respectively, for let-7b (Fig. S6e).

\section{Discussion}

At present, PSA testing is widely used in the clinic for the diagnosis of $\mathrm{PCa}$, but it is not sufficient for an accurate early diagnosis and prognosis. Moreover, some treatments including BPH, glandular inflammation, drug therapy, prostate massage, and the finger test can directly affect serum PSA levels [2]. Additionally, certain types of PCa, such as small cell carcinoma, mostly show normal PSA levels [14]. PSA measurements have also been responsible for misdiagnosis and overtreatment, thereby increasing the unnecessary pain of patients and wasting medical resources. Although PCa is occasionally identified during the pathological examination of BPH specimens, we urgently require a sensitive and accurate biological marker to objectively evaluate the condition with the aim of achieving precise medical treatment.

Multiple studies have recently established an important role for miRNAs in the biological processes of prostate tumors [15]. Mitchell et al. [3] found that tumor-derived miRNAs could stably exist in blood, while Chen et al. [16] recently showed that some miRNAs could accurately distinguish PCa and BPH. Although many studies have investigated miRNAs expressed in PCa [17, 18], few have examined levels before and after treatment, with or without metastasis, or according to the degree of malignant tumor.

In the present study, we found a significantly higher level of miR-1825 expression in the serum of PCa patients than healthy controls. This differed from the results of Taha, and may reflect the analysis of different tissue types or the small sample size [5]. miR-1825 is known to target the inhibition of discoidin domain receptor (DDR)1, which participates in some epithelial-related cancers and may play a role in insulin-like growth factor-1 receptor functional cross talk in cancer progression $[19,20]$. Abnormal miR-1825 levels may result in the accelerated translation and increased expression of DDR 1 , leading to the induction of tumorigenesis. We also found significantly lower levels of miR-1825 expression in PCa patients after treatment compared with before, while PCa patients with a higher TNM grade had significantly higher miR-1825 levels than those with a lower TNM grade. These results suggest that the miR-1825 level is positively correlated with the malignant degree of PCa tumors, which may be useful as a criterion for diagnosis and the evaluation of PCa treatment.

We also found that the expression of serum miR-484 in was significantly lower in PCa patients compared with 
healthy controls. Many studies have reported that the miR484 functional target gene might be $U B R 5$, which is a key regulator in cell signaling [21,22]. This could explain the mechanism of miR-484 in the occurrence and progression of tumors. We only identified a single article about miR484 in $\mathrm{PCa}$, which identified abnormal levels in patient urine [5]. Our study provides further evidence that miR484 has the potential to diagnose PCa.

miR-205 is mainly expressed on the basal cells of prostate tissue and is down-regulated in $\mathrm{PCa}$, which might inhibit tumor growth [23-25]. We detected significantly lower miR205 expression in PCa patients than in healthy controls, and observed a sensitivity of $77.8 \%$ for miR-205 in the diagnosis of distant tumor metastasis, and a specificity of $100 \%$. Previous studies showed that miR-205 is not only involved in the regulation of tumor cell migration, but that its expression is negatively correlated with tumor metastasis [24]. miR-205 levels were also lower in PCa patients with bone metastases [25], which is in line with our current results. We also showed that miR-205 expression was significantly lower in patients with metastatic PCa than in control. miR-205 levels could therefore be used in the early diagnosis of $\mathrm{PCa}$ and the detection of bone metastases.

Tumor-related mutations often occur in the chromosomal region of human let-7b [26], which contributes to the suppression of tumor genes [27]. Previous studies showed that the let-7 family plays an important role in the recurrence and metastasis of PCa by regulating tumor stem cells [8], and in the hormone resistance of tumors [9]. Specifically, let-7b was previously reported to inhibit the growth of tumor stem cells by regulating EZH2 [28]. We observed significantly lower let-7b expression in PCa patients compared with healthy controls, and detected significantly lower levels in patients with high PSA levels, higher TNM staging, and hormone resistance. Our findings indicate that let-7b may be useful as an early diagnostic index for tumor diagnosis, the extent of tumor malignancy, and the assessment of failed hormone therapy. It could also be used to aid early diagnosis and adjust individualized treatment regimens for high-risk PCa.

Additionally, we demonstrated a significant increase in miR-141 levels in PCa patients compared with controls, which was consistent with a previous analysis of serum miRNA expression profiles in PCa patients [29]. AR is a possible target gene of miR-141-3p, which provides an effective focus for targeted PCa treatment [11, 12]. Our findings suggested that serum miR-141 may be a useful prognostic marker for $\mathrm{PCa}$, although it did not appear to distinguish specific patient subgroups.

Our study identified and characterized several potential miRNA markers for $\mathrm{PCa}$, including miR-1825, miR484, miR-205, miR-141, and Let-7b. miR-205 may also be used as a biomarker for indicating bone metastasis in $\mathrm{PCa}$ patients, miR-1825 to indicate tumor TNM classification, evaluate treatment effects, and suggest prognosis, while let-7b levels may indicate tumor malignancy and hormone resistance status and be used to adjust individual treatments for the high-risk, early diagnosis of refractory $\mathrm{PCa}$.

Acknowledgements This study was funded by the Qingdao Science and Technology Bureau (project number: 15-9-2-67-nsh). We are grateful to Shanghai Nobel Bio Ltd. (Shanghai, China) for providing reagents and experimental assistance. We thank Gabrielle White Wolf, $\mathrm{PhD}$, from Edanz Group (http://www.edanzediting.com/ac) for editing a draft of this manuscript.

\section{Compliance with ethical standards}

Conflict of interest All authors declare that there are no competing financial interests.

Open Access This article is distributed under the terms of the Creative Commons Attribution 4.0 International License (http://creativeco mmons.org/licenses/by/4.0/), which permits unrestricted use, distribution, and reproduction in any medium, provided you give appropriate credit to the original author(s) and the source, provide a link to the Creative Commons license, and indicate if changes were made.

\section{References}

1. Fitzmaurice C, Dicker D, Pain A, Hamavid H, Moradi-Lakeh M, MacIntyre MF, Allen C, Hansen G, Woodbrook R, Wolfe C, Hamadeh RR, Moore A, Werdecker A, Gessner BD, Te Ao B, McMahon B, Karimkhani C, Yu C, Cooke GS, Schwebel DC, Carpenter DO, Pereira DM, Nash D, Kazi DS, De Leo D, Plass D, Ukwaja KN, Thurston GD, Yun Jin K, Simard EP, Mills E, Park EK, Catala-Lopez F, deVeber G, Gotay C, Khan G, Hosgood HD 3rd, Santos IS, Leasher JL, Singh J, Leigh J, Jonas JB, Sanabria J, Beardsley J, Jacobsen KH, Takahashi K, Franklin RC, Ronfani L, Montico M, Naldi L, Tonelli M, Geleijnse J, Petzold M, Shrime MG, Younis M, Yonemoto N, Breitborde N, Yip P, Pourmalek F, Lotufo PA, Esteghamati A, Hankey GJ, Ali R, Lunevicius R, Malekzadeh R, Dellavalle R, Weintraub R, Lucas R, Hay R, Rojas-Rueda D, Westerman R, Sepanlou SG, Nolte S, Patten S, Weichenthal S, Abera SF, Fereshtehnejad SM, Shiue I, Driscoll T, Vasankari T, Alsharif U, Rahimi-Movaghar V, Vlassov VV, Marcenes WS, Mekonnen W, Melaku YA, Yano Y, Artaman A, Campos I, MacLachlan J, Mueller U, Kim D, Trillini M, Eshrati B, Williams HC, Shibuya K, Dandona R, Murthy K, Cowie B, Amare AT, Antonio CA, Castaneda-Orjuela C, van Gool CH, Violante F, Oh IH, Deribe K, Soreide K, Knibbs L, Kereselidze M, Green M, Cardenas R, Roy N, Tillmann T, Li Y, Krueger H, Monasta L, Dey S, Sheikhbahaei S, Hafezi-Nejad N, Kumar GA, Sreeramareddy CT, Dandona L, Wang H, Vollset SE, Mokdad A, Salomon JA, Lozano R, Vos T, Forouzanfar M, Lopez A, Murray C, Naghavi M (2015) The global burden of cancer 2013. JAMA Oncol 1(4):505-527. https://doi.org/10.1001/jamao ncol.2015.0735

2. Pron G (2015) Prostate-specific antigen (PSA)-based population screening for prostate cancer: an evidence-based analysis. Ont Health Technol Assess Ser 15(10):1-64

3. Mitchell PS, Parkin RK, Kroh EM, Fritz BR, Wyman SK, Pogosova-Agadjanyan EL, Peterson A, Noteboom J, O'Briant KC, Allen A, Lin DW, Urban N, Drescher CW, Knudsen BS, Stirewalt DL, 
Gentleman R, Vessella RL, Nelson PS, Martin DB, Tewari M (2008) Circulating microRNAs as stable blood-based markers for cancer detection. Proc Natl Acad Sci USA 105(30):10513-10518. https://doi.org/10.1073/pnas.0804549105

4. Ling H, Fabbri M, Calin GA (2013) MicroRNAs and other noncoding RNAs as targets for anticancer drug development. Nat Rev Drug Discov 12(11):847-865. https://doi.org/10.1038/nrd4140

5. Haj-Ahmad TA, Abdalla MA, Haj-Ahmad Y (2014) Potential urinary miRNA biomarker candidates for the accurate detection of prostate cancer among benign prostatic hyperplasia patients. $\mathrm{J}$ Cancer 5(3):182-191. https://doi.org/10.7150/jca.6799

6. Yamada Y, Nishikawa R, Kato M, Okato A, Arai T, Kojima S, Yamazaki K, Naya Y, Ichikawa T, Seki N (2018) Regulation of HMGB3 by antitumor miR-205-5p inhibits cancer cell aggressiveness and is involved in prostate cancer pathogenesis. J Hum Genet 63(2):195-205. https://doi.org/10.1038/s10038-017-0371-1

7. Nordby Y, Richardsen E, Ness N, Donnem T, Patel HRH, Busund LT, Bremnes RM, Andersen S (2017) High miR-205 expression in normal epithelium is associated with biochemical failurean argument for epithelial crosstalk in prostate cancer? Sci Rep 7(1):16308. https://doi.org/10.1038/s41598-017-16556-2

8. Kong D, Heath E, Chen W, Cher ML, Powell I, Heilbrun L, Li Y, Ali S, Sethi S, Hassan O, Hwang C, Gupta N, Chitale D, Sakr WA, Menon M, Sarkar FH (2012) Loss of let-7 up-regulates $\mathrm{EZH} 2$ in prostate cancer consistent with the acquisition of cancer stem cell signatures that are attenuated by BR-DIM. PLoS ONE 7(3):e33729. https://doi.org/10.1371/journal.pone.0033729

9. Paller CJ, Antonarakis ES, Eisenberger MA, Carducci MA (2013) Management of patients with biochemical recurrence after local therapy for prostate cancer. Hematol Oncol Clin N Am 27(6):1205-1219. https://doi.org/10.1016/j.hoc.2013.08.005viii.

10. Brase JC, Johannes M, Schlomm T, Falth M, Haese A, Steuber T, Beissbarth T, Kuner R, Sultmann H (2011) Circulating miRNAs are correlated with tumor progression in prostate cancer. Int $\mathrm{J}$ Cancer 128(3):608-616. https://doi.org/10.1002/ijc.25376

11. Yaman Agaoglu F, Kovancilar M, Dizdar Y, Darendeliler E, Holdenrieder S, Dalay N, Gezer U (2011) Investigation of miR-21, miR-141, and miR-221 in blood circulation of patients with prostate cancer. Tumour Biol 32(3):583-588. https://doi.org/10.1007/ s13277-011-0154-9

12. Yang Z, Wang L (2011) Regulation of microRNA expression and function by nuclear receptor signaling. Cell Biosci 1(1):31. https ://doi.org/10.1186/2045-3701-1-31

13. Livak KJ, Schmittgen TD (2001) Analysis of relative gene expression data using real-time quantitative PCR and the $2^{-\Delta \Delta C}$ Method. Methods (San Diego Calif) 25(4):402-408. https://doi. org/10.1006/meth.2001.1262

14. Chen H, Sun Y, Wu C, Magyar CE, Li X, Cheng L, Yao JL, Shen S, Osunkoya AO, Liang C, Huang J (2012) Pathogenesis of prostatic small cell carcinoma involves the inactivation of the P53 pathway. Endocr Relat Cancer 19(3):321-331. https://doi. org/10.1530/erc-11-0368

15. Cannistraci A, Di Pace AL (2014) MicroRNA as new tools for prostate cancer risk assessment and therapeutic intervention: results from clinical data set and patients' samples. BioMed Res Int 2014:146170. https://doi.org/10.1155/2014/146170

16. Chen ZH, Zhang GL, Li HR, Luo JD, Li ZX, Chen GM, Yang J (2012) A panel of five circulating microRNAs as potential biomarkers for prostate cancer. Prostate 72(13):1443-1452. https:// doi.org/10.1002/pros.22495

17. Sita-Lumsden A, Dart DA, Waxman J, Bevan CL (2013) Circulating microRNAs as potential new biomarkers for prostate cancer. Br J Cancer 108(10):1925-1930. https://doi.org/10.1038/ bjc. 2013.192

18. Wang J, Huang SK, Zhao M, Yang M, Zhong JL, Gu YY, Peng H, Che YQ, Huang CZ (2014) Identification of a circulating
microRNA signature for colorectal cancer detection. PLoS ONE 9(4):e87451. https://doi.org/10.1371/journal.pone.0087451

19. Weiner HL, Huang H, Zagzag D, Boyce H, Lichtenbaum R, Ziff EB (2000) Consistent and selective expression of the discoidin domain receptor-1 tyrosine kinase in human brain tumors. Neurosurgery 47(6):1400-1409

20. Malaguarnera R, Nicolosi ML, Sacco A, Morcavallo A, Vella V, Voci C, Spatuzza M, Xu SQ, Iozzo RV, Vigneri R, Morrione A, Belfiore A (2015) Novel cross talk between IGF-IR and DDR1 regulates IGF-IR trafficking, signaling and biological responses. Oncotarget 6(18):16084-16105. https://doi.org/10.18632/oncot arget. 3177

21. Henderson MJ, Munoz MA, Saunders DN, Clancy JL, Russell AJ, Williams B, Pappin D, Khanna KK, Jackson SP, Sutherland RL, Watts CK (2006) EDD mediates DNA damage-induced activation of CHK2. J Biol Chem 281(52):39990-40000. https://doi. org/10.1074/jbc.M602818200

22. Clancy JL, Henderson MJ, Russell AJ, Anderson DW, Bova RJ, Campbell IG, Choong DY, Macdonald GA, Mann GJ, Nolan T, Brady G, Olopade OI, Woollatt E, Davies MJ, Segara D, Hacker NF, Henshall SM, Sutherland RL, Watts CK (2003) EDD, the human orthologue of the hyperplastic discs tumour suppressor gene, is amplified and overexpressed in cancer. Oncogene 22(32):5070-5081. https://doi.org/10.1038/sj.onc.1206775

23. Wang N, Li Q, Feng NH, Cheng G, Guan ZL, Wang Y, Qin C, Yin CJ, Hua LX (2013) miR-205 is frequently downregulated in prostate cancer and acts as a tumor suppressor by inhibiting tumor growth. Asian J Androl 15(6):735-741. https://doi.org/10.1038/ aja.2013.80

24. Tucci P, Agostini M, Grespi F, Markert EK, Terrinoni A, Vousden KH, Muller PA, Dotsch V, Kehrloesser S, Sayan BS, Giaccone G, Lowe SW, Takahashi N, Vandenabeele P, Knight RA, Levine AJ, Melino G (2012) Loss of p63 and its microRNA-205 target results in enhanced cell migration and metastasis in prostate cancer. Proc Natl Acad Sci USA 109(38):15312-15317. https://doi. org/10.1073/pnas.1110977109

25. Gandellini P, Folini M, Longoni N, Pennati M, Binda M, Colecchia M, Salvioni R, Supino R, Moretti R, Limonta P, Valdagni R, Daidone MG, Zaffaroni N (2009) miR-205 exerts tumor-suppressive functions in human prostate through down-regulation of protein kinase Cepsilon. Cancer Res 69(6):2287-2295. https://doi. org/10.1158/0008-5472.can-08-2894

26. Schubert M, Spahn M, Kneitz S, Scholz CJ, Joniau S, Stroebel P, Riedmiller H, Kneitz B (2013) Distinct microRNA expression profile in prostate cancer patients with early clinical failure and the impact of let-7 as prognostic marker in high-risk prostate cancer. PLoS ONE 8(6):e65064. https://doi.org/10.1371/journ al.pone. 0065064

27. Chen F, Chen C, Yang S, Gong W, Wang Y, Cianflone K, Tang J, Wang DW (2012) Let-7b inhibits human cancer phenotype by targeting cytochrome P450 epoxygenase $2 \mathrm{~J} 2$. PLoS ONE 7(6):e39197. https://doi.org/10.1371/journal.pone.0039197

28. Cookson MS, Aus G, Burnett AL, Canby-Hagino ED, D'Amico AV, Dmochowski RR, Eton DT, Forman JD, Goldenberg SL, Hernandez J, Higano CS, Kraus SR, Moul JW, Tangen C, Thrasher JB, Thompson I (2007) Variation in the definition of biochemical recurrence in patients treated for localized prostate cancer: the American Urological Association Prostate Guidelines for Localized Prostate Cancer Update Panel report and recommendations for a standard in the reporting of surgical outcomes. J Urol 177(2):540-545. https://doi.org/10.1016/j.juro.2006.10.097

29. Lodes MJ, Caraballo M, Suciu D, Munro S, Kumar A, Anderson B (2009) Detection of cancer with serum miRNAs on an oligonucleotide microarray. PLoS ONE 4(7):e6229. https://doi.org/10.1371/ journal.pone.0006229 